\title{
Summer Education Internship Program
}

\section{Dr. Asad Yousuf, Savannah State University}

Asad Yousuf is the Coordinator and Professor of Electronics Engineering Technology at Savannah State University

\section{Dr. Mohamad A. Mustafa, Savannah State University}

Mohamad Mustafa is a Professor of Civil Engineering Technology and the Chair of the Engineering Technology Department at Savannah State University (SSU). He has six years of industrial experience prior to teaching at SSU. He received his BS, MS, and PhD in Civil Engineering from Wayne State University, Detroit, Michigan.

\section{Dr. Keenya Mosley, Savannah State University}

Dr. Keenya G. Mosley serves as the Assessment \& CAEP Manager/Assistant Professor for the School of Teacher Education at Savannah State University. As the first faculty hired, she has assisted with designing and preparing the unit which received state approval from the Georgia Professional Standards Commission. She has over 10 years of assessment experience and serves as the edTPA Coordinator for Savannah State University. Her role as the Assessment Manager includes serving on institutional and state assessment committees while preparing students and supporting faculty and collaborating teachers on using the assessment system. Dr. Mosley has recently be selected to serve as a Site Visitor with the Georgia Professional Standards Commission/Council for the Accreditation of Educator Preparation. Her teaching experience spans across secondary, adult, technical and higher education. She has presented at state, regional, national and international conferences and has several publications. She has served on accreditation committees, K-12 school committees and local community boards and received and managed over two million dollars in federal grants. In addition, Dr. Mosley serves on state and national committees for teacher education.

\section{Dr. Mir M. Hayder, Savannah State University}

Dr. Hayder is an Associate Professor in the Department of Engineering Technology at Savannah State University, GA. He received PhD in Mechanical Engineering from McGill University, Canada. His research interest lies in the areas of engineering education, fluid-structure interaction, flow-induced vibrations, syngas and blended fuel combustion, nanofluids, and flow and structural simulations.

\section{Mr. Christopher S. Stronen, Savannah Technical College}

I am a student attending Savannah Technical College pursuing the Electrical and Computer Engineering Associates Degree. I have completed two internships of the NOYCE Summer Program.

In the Fall 2017 I will transfer to Savannah State to finish the Electrical Engineering Technology Bachelor's Program and successfully pass my FE exam to become a certified Engineer for the state of Georgia. 


\title{
Summer Educational Internship Program
}

\begin{abstract}
K-12 school teachers in general lack formal instruction and classroom training to teach STEM courses. Research also, indicates that most K-12 teachers are normally required to complete only minimal coursework in science and mathematics, which constrains their knowledge, ability, and confidence for teaching STEM (Science, Technology, Engineering and Math) content.

Furthermore, K-12 teachers, like much of the general public, have inadequate comprehension about the relationship between STEM concepts and engineering fields and the kind of work and collective contributions made by engineers. Yet, $\mathrm{K}-12$ school is a critical time in which students develop foundational understanding of STEM concepts, career options, and critical thinking learning skills.

To address the aforementioned issues Savannah State University and Savannah Technical College in collaboration with NASA developed four week Summer Educational Internship Program for Math and Engineering Technology rising sophomore students to prepare them for two week teaching experience with students in grades 6-12. Fifteen (12 from Savannah State University and 3 from Savannah Technical College) students were selected to participate in the Summer Educational Internship Program (SEIP) and was offered a stipend of \$1000. Several instructional models were explored for teaching mathematics and engineering at grades 6-12 levels. Summer educational internship program was divided into three different phases. In phase I students attended a week course offered by NASA which provided them with hands on activities that can be integrated in teaching of STEM from 6-12 grades, in phase II summer interns were given assistance on teaching methodologies and in phase III summer interns were involved in teaching students from 6-12 grades. This paper will describe all three phases of summer educational internship program to enhance the interest of summer interns in STEM disciplines.
\end{abstract}

\section{Introduction}

President Obama in his address to the National Academics of Science in 2009 quoted a BusinessHigher Education Forum report (2007) stating "There is a projected shortfall of more than 280,000 math and science teachers across the country by 2015". This need will have a strong effect in high need school districts and thus the President's Educate to Innovate campaign (2010) calls for an increase in "STEM literacy so that all students can learn deeply and think critically in science, math, engineering, and technology."

STEM is primary driver of the future economy and hence the increasing number of jobs at all levels require knowledge of STEM [1]. Research shows that insufficient training, time, and incentives are among the most commonly cited barriers for faculty effectiveness [2]. Many faculty have indicated that in terms of training they feel not well equipped and prepared to meet the challenges that comes along in teaching STEM. Furthermore, research also suggest that the teachers may not be having a deep understanding about what constitutes a student centered classroom [3]. These reviews clearly indicate that there are many perspectives and approaches to 
change that will aid in improving the complex higher education system. We are aware that certain approaches are a good fit for certain conditions but we lack an organized way of thinking about which change perceptions are most appropriate in a given condition. Researchers suggests Four Categories model developed by Henderson and colleagues, an interdisciplinary team that included physics education researchers who explicitly focused on their analysis on change in STEM higher education[4]. On the basis of a literature review of 191 journal articles published between 1995 and 2008, Henderson et al [4] developed the four categories of change strategies model to classify strategies that have been used to conceptualize or to create change in undergraduate STEM education. The similarity of these categories to those developed through an independent review of an overlapping literature base [5] suggests that the four categories are robust and meaningful. Following are the four categories:

- Disseminating Curriculum and Pedagogy: This category is based on the phenomena of tell/teach individuals about new teaching conceptions and/or practices and encourage their use.

- Developing Reflective Teachers: Encourage/Support individuals to develop new teaching conceptions and/or practices

- Enacting Policy: Enact new environmental features that require/encourage new teaching conceptions and/or practices.

- Developing shared vision: Empower/Support stakeholders to collectively develop new environmental features that encourage new teaching conceptions and/or practices.

\section{Summer Educational Internship Program (SEIP-2016)}

The backbone to increase the STEM graduates is increase the high quality STEM teachers. Savannah State University and Savannah Technical College in collaboration with NASA modelled a Summer Educational Internship program that was funded by NSF-Robert Noyce Scholarship program to foster teaching career paths for middle and high school teachers to meet the demands of STEM teachers in the Savannah Chatham County Public school system. Specific elements of the program include the following:

1. Launching an aggressive recruitment plan for talented math and engineering majors to pursue teaching careers in 6-12 secondary schools;

2. Implementing a comprehensive STEM teacher training program;

3. Providing Summer Educational Internship Program (SEIP) to rising sophomores;

4. Providing Field Observation Experiences for sophomores;

5. Providing $\$ 10,000$ scholarships to talented math and engineering juniors and seniors to pursue teaching career by acquiring education training through SSU teacher education math, civil, and electronics engineering technology programs;

6. Providing $\$ 10,000$ stipends for STEM professionals or recent STEM graduates to become teachers;

7. Enhancing the local district's teacher mentoring and professional development program to improve teacher performance and retention

This paper will describe the four week Summer Education Internship program which provides opportunities to the students who are considering teaching careers to get exposure to the field of teaching so that they find out if they are interested in teaching. 
Savannah State University, Savannah Technical College and NASA representative developed and implemented a four week SEIP-2016 for STEM rising sophomore students to engage them in teaching experience. SEIP offered 15 students an internship in the summer of 2016 (12 from Savannah State University and 3 from Savannah technical college) and the participants received $\$ 1000$ stipend for the four week period.

The SEIP-2016 summer internship for participating sophomores was intended to allow students to experience the role of a teacher and to train the students in certain techniques designed to captivate and inspire younger K-12 students to pursue careers in the STEM fields [6]. To prepare the NOYCE interns they were transported to the Kennedy Space Center located in Titusville, Florida to be instructed by the head of the education department of NASA. This instruction lasted for one week in which the students were trained for three hours each day, completing various projects and being assigned homework after class. After the training received at the Kennedy Space Center the students were split into two groups; those which would teach elementary students at Oglethorpe Academy and those which would teach high school students enrolled in the Upward Bound Program at Savannah State University. Table 1 shows SEIP activities. The SEIP program requires that student must participate in teaching field experience.

Table 1.0: SEIP Activities

\begin{tabular}{|c|c|c|c|c|c|}
\hline $\begin{array}{l}\text { Week } 1 \\
\text { NASA }\end{array}$ & $\begin{array}{l}\text { Day 1 } \\
\text { Orientation } \\
\text { NASA } \\
\text { representatives }\end{array}$ & $\begin{array}{l}\text { Day } 2 \\
\text { Project } 1 \\
\text { Platform to } \\
\text { support two } \\
\text { rockets with } \\
\text { cargo }\end{array}$ & $\begin{array}{l}\text { Day } 3 \\
\text { Project } 2 \\
\text { Construct a tower to } \\
\text { stand by itself with } \\
\text { no support }\end{array}$ & $\begin{array}{l}\text { Day } 4 \\
\text { Project } 3 \\
\text { Build a rocket that } \\
\text { will be able to carry } \\
\text { cargo to Mars }\end{array}$ & $\begin{array}{l}\text { Day } 5 \\
\text { Assessment } \\
\text { And Facility } \\
\text { tour }\end{array}$ \\
\hline $\begin{array}{l}\text { Week } 2 \\
\text { Student } \\
\text { mentoring } \\
\text { XXX }\end{array}$ & $\begin{array}{l}\text { Day } 1 \\
\text { Lessons plans to } \\
\text { implement } \\
\text { NASA activities }\end{array}$ & $\begin{array}{l}\text { Day } 2 \\
\text { How to manage } \\
\text { learning through } \\
\text { NASA activities }\end{array}$ & $\begin{array}{l}\text { Day } 3 \\
\text { Instruction/Teachin } \\
\text { g Methodologies to } \\
\text { implement NASA } \\
\text { activities }\end{array}$ & $\begin{array}{l}\text { Day } 4 \\
\text { Work with the } \\
\text { discipline area } \\
\text { mentors to develop } \\
\text { math and engineering } \\
\text { skills needed for } \\
\text { NASA activities }\end{array}$ & $\begin{array}{l}\text { Day } 5 \\
\text { Assessment }\end{array}$ \\
\hline $\begin{array}{l}\text { Week } 3 \\
\text { Oglethorpe } \\
\text { Academy } \\
\text { Technology } \\
\text { Week } \\
\text { Elementary } \\
\text { School students } \\
\end{array}$ & $\begin{array}{l}\text { Day 1 } \\
\text { 9:00 -12:00PM } \\
\text { NASA activities } \\
\text { 12:00PM - } \\
\text { 1:00PM } \\
\text { Mentoring } \\
\text { /Assessment } \\
\end{array}$ & $\begin{array}{l}\text { Day } 2 \\
\text { 9:00 -12:00PM } \\
\text { NASA activities } \\
\text { 12:00PM - } \\
\text { 1:00PM } \\
\text { Mentoring } \\
\text { /Assessment } \\
\end{array}$ & $\begin{array}{l}\text { Day } 3 \\
\text { 9:00 -12:00PM } \\
\text { NASA activities } \\
\text { 12:00PM -1:00PM } \\
\text { Mentoring } \\
\text { /Assessment }\end{array}$ & $\begin{array}{l}\text { Day } 4 \\
\text { 9:00 -12:00PM } \\
\text { NASA activities } \\
\text { 12:00PM -1:00PM } \\
\text { Mentoring } \\
\text { /Assessment }\end{array}$ & $\begin{array}{l}\text { Day } 5 \\
\text { 9:00 -12:00PM } \\
\text { NASA activities } \\
\text { 12:00PM - } \\
\text { 1:00PM } \\
\text { Mentoring } \\
\text { /Assessment }\end{array}$ \\
\hline $\begin{array}{l}\text { Week } 4 \\
\text { Oglethorpe } \\
\text { Academy } \\
\text { Middle School } \\
\text { students }\end{array}$ & $\begin{array}{l}\text { Day 1 } \\
\text { 9:00-12:00PM } \\
\text { NASA activities } \\
\text { 1200PM - } \\
\text { 100PM } \\
\text { Mentoring } \\
\text { /Assessment }\end{array}$ & $\begin{array}{l}\text { Day } 2 \\
\text { 9:00-12:00PM } \\
\text { NASA activities } \\
\text { 1200PM - } \\
\text { 100PM } \\
\text { Mentoring } \\
\text { /Assessment }\end{array}$ & $\begin{array}{l}\text { Day 3 } \\
\text { 9:00-12:00PM } \\
\text { NASA activities } \\
\text { 1200PM -100PM } \\
\text { Mentoring } \\
\text { /Assessment }\end{array}$ & $\begin{array}{l}\text { Day } 4 \\
\text { 9:00-12:00PM } \\
\text { NASA activities } \\
\text { 1200PM -100PM } \\
\text { Mentoring } \\
\text { /Assessment }\end{array}$ & $\begin{array}{l}\text { Day 5 } \\
\text { 9:00-12:00PM } \\
\text { NASA activities } \\
\text { 1200PM - } \\
\text { 100PM } \\
\text { Mentoring } \\
\text { /Assessment }\end{array}$ \\
\hline
\end{tabular}

\section{Phase I NASA Instruction/Training}

Four days the interns attended a course given on Kennedy Space Center grounds. In the course there were two objectives. The first objective was to provide training in teaching K-12 students STEM subjects. The second objective was to inform the interns of the opportunities available in 
the education field and how teachers have a profound effect on society [7]. Each class day the instructor gave a lecture and presented relevant information on a projector screen. The interns were first educated on the fundamental role of a teacher - to shape society's future for the better by shaping the minds of younger generation. After, opportunities available at NASA in terms of education were presented and the students were informed of how involved the space agency is in providing teachers with resources such as course materials and school trips. A few example lessons were given by the instructor; explaining the mechanics of a rocket, elaborating on the evidence of global warming, and presenting the benefits that could be yielded from exploration of mars.

After these fundamentals had been conveyed, the interns were then taught how to conduct lessons that would engross a classroom composed of students $\mathrm{k}-6$. These lessons were mainly projects designed to make children think mechanically and produce mechanisms made of common office materials that would perform a specified task [8]. Each of the mechanisms were intended to mimic real machines employed by NASA. In order to allow the interns to understand the implications of the lesson in terms of engrossing students and stimulating their minds, the instructor had the interns compete against each other, competing to see who could construct the mechanism in the best way so that the mechanism performed its preferred task.

The list of projects given by the instructor is shown below along with all the materials provided during the course:

Project 1: Construct a platform by itself without fixing it to the ground and it needs to be able to hold two different types of rockets with full cargo!

Supplies:

Straws (30), 20 flexi straw, 5 non flexi, 5 stir straws, Scissors (1), Cups (2), Paper 3 oz and 5 oz, Pebbles/marbles (to fill cups), Index card (2), Balance, Tape, Masking Tape $(30 \mathrm{~cm})$ or Scotch Tape/Clear $(40 \mathrm{~cm})$.

Project 2: Construct a tower to stand by itself without any support from walls, tables, chairs, etc. It needs to measure 1.2 meters tall!

Supplies:

Straws (30), 20 flexi straw, 5 non flexi, 5 stir straws, Scissors (1), Index Card (2), Balance, Taps, Masking Tape $(20 \mathrm{~cm})$ or Scotch Tape/Clear $(30 \mathrm{~cm})$.

Project 3: Build a rocket that will be able to carry cargo to Mars in the shortest of time possible with the heaviest of cargo capabilities.

Supplies:

3 meters of fishing wire, 3 balloons ( 7 inch), Tape $(30 \mathrm{~cm}), 10$ paper clips, One cup (paper) 3oz or 4oz, Pebbles (5) for cargo, 2 Flexi straw.

Project 3 Continued: Once we travel across the solar system we need to land. NASA will also need to land the astronauts safely otherwise it is a failed mission. The landing needs to be extremely soft, so the astronauts don't fall out. 
Supplies:

1 piece of cardboard (approximately 4 x $5 \mathrm{in} / 10 \times 13 \mathrm{~cm}$ ), 1 small paper or plastic cup 3 oz or 4 oz, 3 index cards ( 3 x $5 \mathrm{in} / 8 \times 13 \mathrm{~cm}$ ), 2 regular marshmallows, 10 miniature marshmallows, 3 rubber bands, 8 plastic straws, Scissors.

\section{Phase II: Teaching Methodologies}

The interns were split into two groups. The first group was to teach elementary and middle school students at Oglethorpe Academy while the second was to teach high school students at Savannah State University. The group responsible for teaching the high school students was referred to as the Upward Bound group because that group was to instruct high school students who were participating in the Upward Bound Summer program.

For the first two weeks after returning from the Kennedy Space Center, the interns were given lectures on the components of a lesson. They were informed on how to capture the students' attention by way of an interesting introduction and then to impart the information in a fun and interesting way so that the concepts being conveyed were reinforced in the children's minds. The conclusion was to always be used for the purpose of highlighting the most important points of the lesson and to help the students understand how the lesson is applicable to their lives [8].

The interns were given an outline of their lessons by way of a lesson plan sheet. With the lesson plan sheet the interns plotted out how their lessons would be conducted in chronological order. They also selected which methods would be used to teach. The lesson plan would also have to address various problems that could come up in the classroom such as children suffering from handicaps or if a large segment of the classroom did not have the academic background to satisfy the lesson. The Oglethorpe interns formed themselves into groups of three and devised their plans with the knowledge that their lessons would mimic the projects performed while at NASA. The Upward Bound interns, of which there were three, were each responsible for their own classes. After devising appropriate lesson plans, the interns presented their plans to the rest of the class and the teaching instructor would give her remarks and supply advice.

\section{Part III Teaching in the Classroom}

The Oglethorpe group was given one week to rehearse and perfect their performance. Out of these interns there were groups of three and each day of the week they met in a computer lab. They were to mimic the class taught at the Kennedy Space Center, instructing their students to construct mechanisms made from office products. Together they brainstormed how to improve upon the lessons and picked out projects that would better suit which concepts they wanted to teach.

The Oglethorpe group taught their classes for one week. Their students enjoyed the projects tremendously and internalized the concepts which the interns wished to convey. The children found the classes very enjoyable and were delighted when they saw that they could make rockets and launch pads out of everyday office products.

The Upward Bound group was given four weeks to perfect their lessons. Their group consisted of three interns and each was responsible for teaching a particular subject. One intern was 
responsible for teaching computer programming with the scratch application, another intern programming robots in $\mathrm{P}$ basic, and the final intern $3 \mathrm{~d}$ industrial development with solidworks.

The intern responsible for teaching computer programming was to teach five classes. In each class there would be an objective to be achieved. In the first class the intern taught the students how to create sprites on the Scratch Application. The students learned how to use the pen tool and the paint tools in order to make a look-alike of themselves. They then were shown how to use the speech function and the wait function in order to have their sprite talk with text bubbles that would appear after an allotted time. In the second class the intern taught the students animation with keyframes in order to simulate the illusion of movement. In the third class the intern instructed the students in creating their first ping pong video game. The intern taught them how to instruct their sprites to move in accordance to certain rules and showed them the relation of position to $\mathrm{x}$ and $\mathrm{y}$ coordinates. In the fourth class the intern presented the students with a piece of code that employed the use of trigonometric functions in order to simulate an orbit around a point of reference. The students were able to replicate the code and also designed their own solar systems. In the fifth class the intern presented the students with a game that was inherently flawed and could only be solved by correcting the code. In the game there was a car which would navigate a maze but at the midpoint of the level would transport back to the beginning. The students found this puzzle very entertaining and eventually fixed the problem.

The intern responsible for teaching programming robots in $\mathrm{P}$ basic was to teach four classes. In each class the students were to make a robot move in a distinct pattern by programming the robot and later by using the aid of detection devices. The robot consisted of a circuit board embedded onto a platform suspended on wheels. In the first class the intern instructed the students how to program their robot to move forward and backward. In the second class the intern instructed the students to program their robot to move at various angles and then to come back to its original position. In the third class the intern instructed the students to program their robot to avoid barriers with the aid of infrared sensors. In the fourth class the students were told to program their robots to follow a specific path. As an incentive the intern made it into a competition to see which student could most accurately follow the path.

The intern responsible for teaching 3D industrial development with solidworks taught four classes. As solidworks has a very high learning curve the intern had the students complete two projects in the course of four classes. In the first two classes, the intern taught the students how to construct a launchpad in the solidworks application. The intern showed them how to use basic tools in order to convert a 2D schematic into a 3D rendering. In the last two classes the intern had the students apply their newly learned skills in designing a rocket support.

The students greatly enjoyed each of the interns' courses. They appreciated learning practical skills and the challenge of the lessons. The success of each project did not come easily but the students came away from the course with a sense of accomplishment and pride.

Figure 1 shows the SEIP Intern Evaluation by STEM 360 students, figure 2 shows the SEIP intern NASA Training Survey and Figure 3.0 shows images taken during the program. 


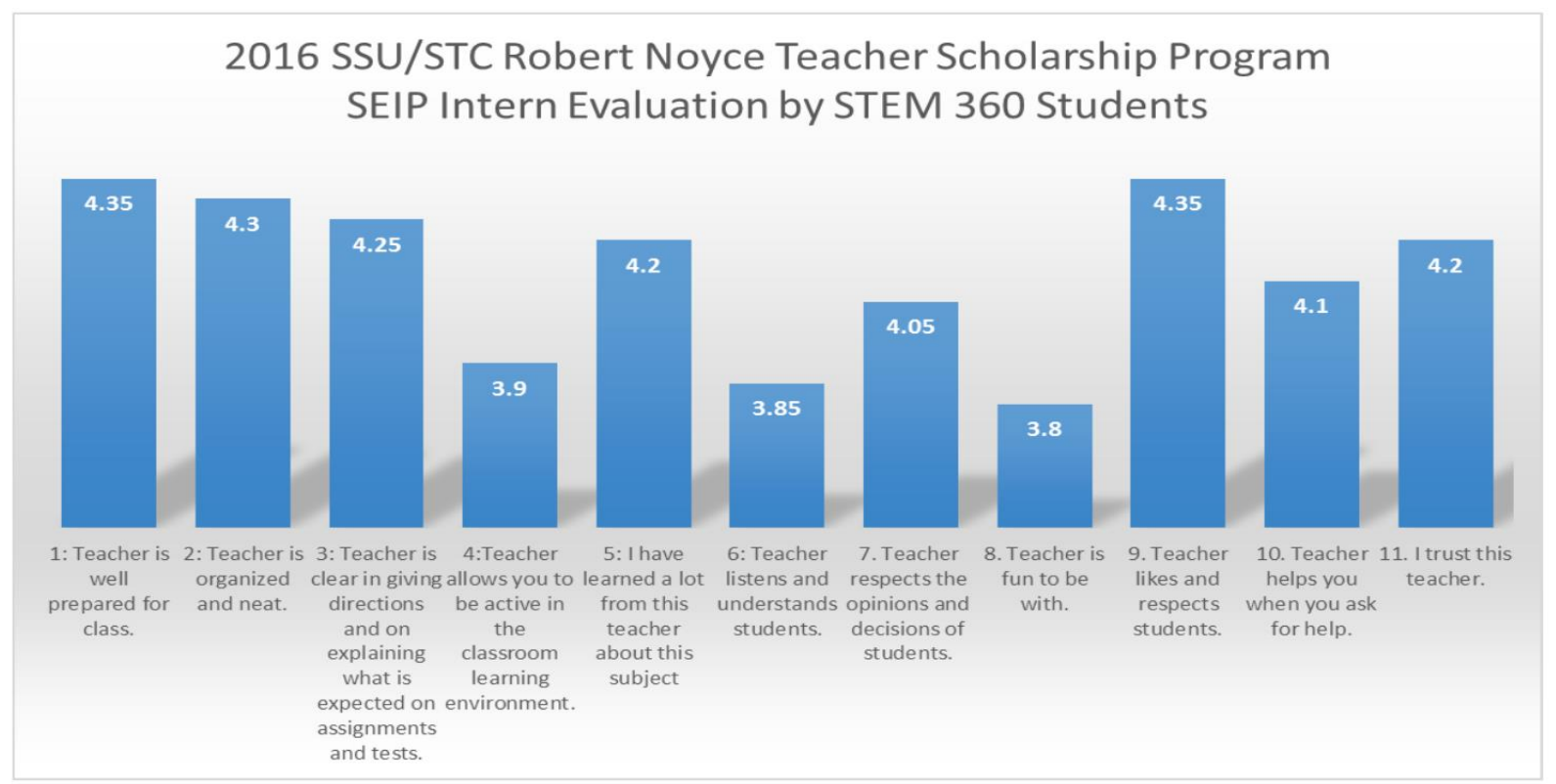

Figure 2: SEIP Intern Evaluation by STEM 360 Students

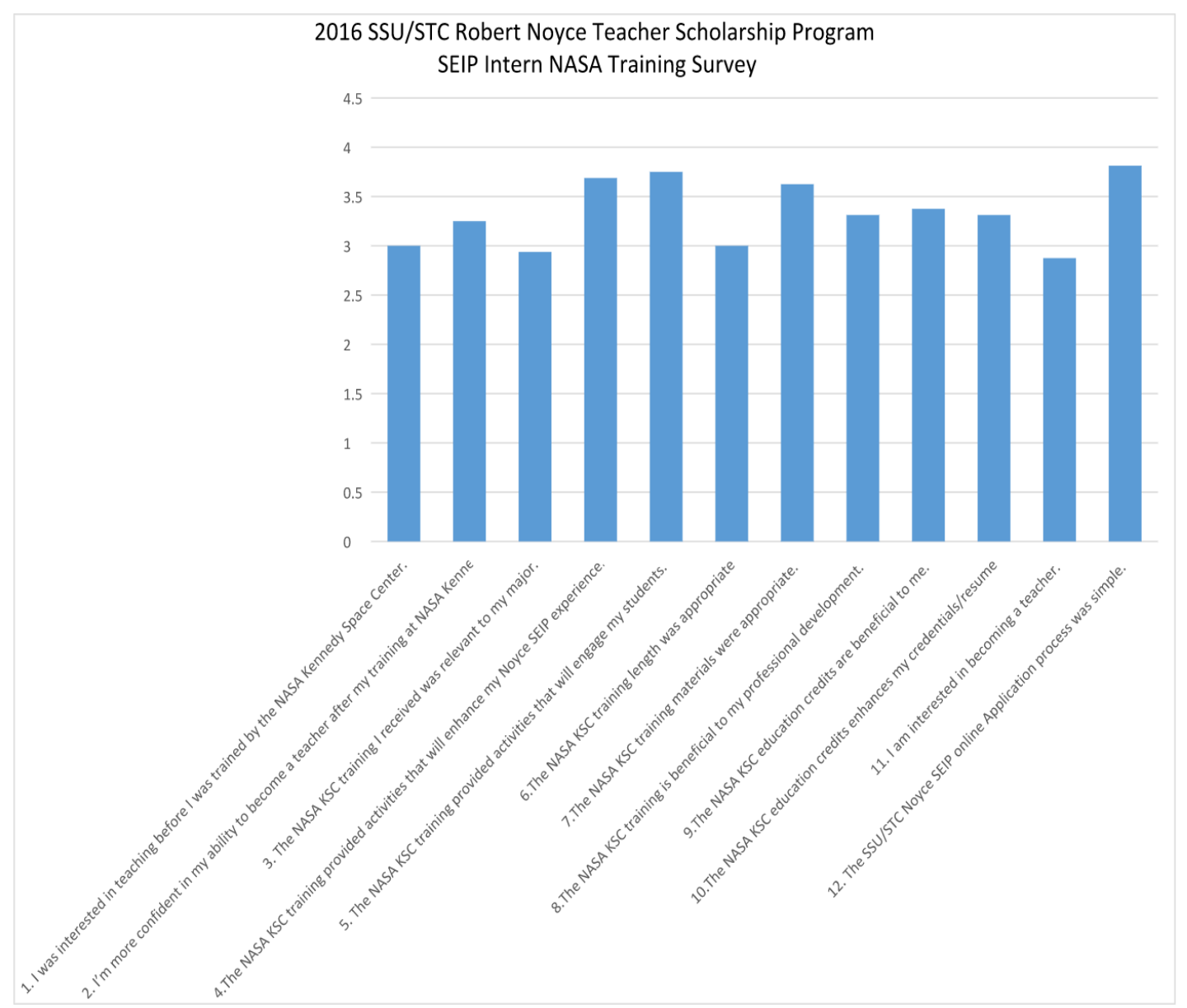

Figure 1: SEIP Intern NASA Training Survey 


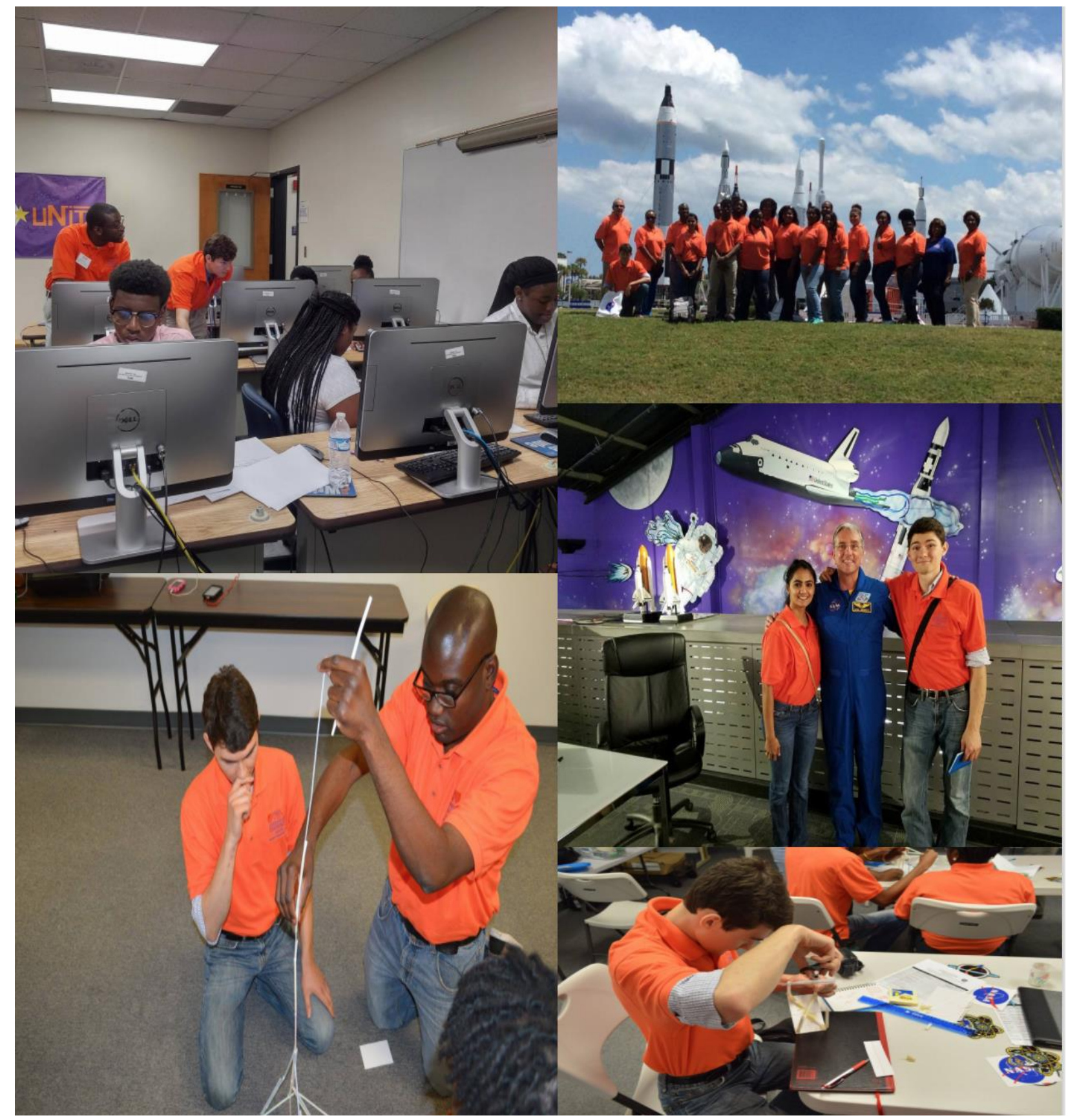

Figure 3: Images taken of interns during the course of the NOYCE summer program

\section{Conclusion}

Based on the data retrieved from the students and the interns, both groups participating in the NOYCE program expressed a new level of interest in the STEM field. The interns developed an appreciation for teaching and were shown how seriously various organizations take the role of the teacher in terms of impacting society. All interns expressed a desire to enter into the teaching field during and after the program. The students graded all of the interns with high scores thus 
affirming the effectiveness of the teaching preparation period. The students also expressed an interest in having careers in the STEM field after receiving instruction.

These results prove that the NOYCE Summer Program met and even exceeded its objectives to introduce rising sophomores studying STEM subjects to the teaching field and successfully winning the interest of students due to effective preparation by the teaching supervisors. Next year we intend to involve interns to participate and assist the Upward Bound program faculty members in teaching Science, Technology, Engineering and Mathematics (STEM) to high school students.

\section{References}

[1] Successful K-12 STEM Education: Identifying Effective Approaches in Science, Technology, Engineering and Mathematics. The National Academies Press, chapter 3, 2011.

[2] A Brief Review of the Preparation of Kentucky Mathematics and Science Teachers, Terry Hibpshman, August 27, 2007.

[3] Hui-Hui Wang, Tamara J. Moore, Gillian H. Roehrig and Mi Sun Park, STEM Integration: Teacher Perceptions and Practice.. Journal of Pre-College Engineering Education Research 2011.

[4] Charles Henderson, Andrea Beach and Noah Finkelstein. Four categories of change strategies for transforming undergraduate education. Chenders publication 2011.

[5] Brainard, J. The tough road to better science teaching. The Chronicle of Higher education 53(48), A16; 2007

[6]Connelly, M. R., \& Millar, S. B. (2006). Using workshops to improve instruction in STEM Courses. Metropolitan Universities, 17(4), 53-65.

[7] Dickie, L. O., Dedic, H., Rosenfield, S., Rosenfield, E., \& Simon, R. A. (2006). Success and persistence in science: The influence of classroom climate. Arxiv preprint physics/ 0610243. Retrieved from http://arxiv.org/pdf/physics/0610243.pdf

[8] Felder, R. M., Brent, R., \& Prince, M. J. (2011). Engineering instructional development: Programs, best practices, and recommendations. Journal of Engineering Education, 100 (1), 89-122.

[9]Hora, M. T. (2012). Organizational factors and instructional decision-making: A cognitive perspective. Review of Higher Education, 35 (2), 207-235. 